\title{
Szabadidő és kulturális fogyasztás a Kárpát- medencei magyar fiatalok körében
}

\section{Bevezetés}

Jelen tanulmány a határon túli magyar fiatalok szabadidős és kulturális fogyasztási szokásait vizsgálja. Áttekintjük a fiatalok szabadidős magatartásában bekövetkezett változásokat, és a kulturális fogyasztás intenzitásának mérőszámait a különböző határon túli régiókban: Felvidéken, Erdélyben, Vajdaságban és Kárpátalján.

Egy korábbi tanulmányunk részletesen elemzi az erdélyi magyar fiatalok kulturális szegmentációját, ${ }^{1}$ ezúttal az elemzést kiterjesztjük a felvidéki, vajdasági és kárpátaljai fiatalokra is, és megnézzük, hogy milyen kulturális fogyasztásbeli jellegzetességek alapján különülnek el a régióbeli magyar fiatalok. Arra vagyunk kíváncsiak, hogy az erdélyi fiatalokhoz hasonló vagy eltérő fogyasztói stílusokat határozhatunk meg a Kárpát-medence többi régiójában, majd áttekintjük a kulturális rétegződés néhány jellemzőjét.

\section{Elméletek és kutatási kérdések}

Kutatási kérdéseink abból a felismerésből bontakoztak ki, hogy a 20. század második felében Nyugat-Európában is kialakult egy posztmodern értékeken alapuló fogyasztói társadalom, melynek érezhető jelei a kilencvenes évek elején a posztszocialista országokba is megérkeztek. A szükös életmódot felváltotta a fogyasztás kultúrája, a korábbi hiánygazdaság helyére a modern fogyasztói társadalom, a túltermelés lépett, ami a fiatalok szabadidős forgatókönyvét is jelentősen befolyásolta.

Thorstein Veblen vizsgálta az elsők között a fogyasztás mozgatórugóját, és azt állítja, hogy a fogyasztási expanzió átalakítja a fogyasztói szokásokat, sokak számára elérhetővé tette azon javak tömeges fogyasztását, melyek korábban luxuscikknek számítottak. ${ }^{2}$ Jean Baudrillard Veblenhez hasonlóan vélekedik,

\footnotetext{
* A szerző a Budapesti Corvinus Egyetem doktorjelöltje, a Max Weber Társadalomkutatásér Alapítvány igazgatója, a Babeş-Bolyai Tudományegyetem Qualitas Központ munkatársa. Email: julia.szabo.05@gmail.com

1 Szabó Júlia: Kulturális szegmentáció az erdélyi magyar fiatalok körében. Socio.hu, 2018/3.

2 Veblen, Thorstein: A dologtalan osztály elmélete. Budapest: Közgazdasági és Jogi, 1975.
} 
a fogyasztásról mint jelbeszédről beszél, aminek többrétü üzenete van. Egyrészt a fogyasztó társadalmi státusát fejezi ki, másrészt pedig a fogyasztó értékpreferenciáját jeleníti meg. Nem is annyira a tárgy a fontos, hanem az ezzel járó státusz, életstílus és életforma. ${ }^{3}$ Azt is mondhatnánk, hogy a fogyasztói társadalomban a fogyasztás identitásképző tevékenységgé válik, vagyis az emberek árucikkek által alakítják személyiségüket. Fogyasztás közben szociális normáknak engedelmeskednek, fogyasztási szokásaikkal pedig üzeneteket küldenek mások felé. Pierre Bourdieu pedig a La distinction könyvében a fogyasztás és a társadalomszerkezet kölcsönhatásait vizsgálta. Megközelítése szerint a mező - mely pozíciók közötti viszonyok összessége - és a habitus, mint a gondolkodási és cselekvési diszpozíciók rendszere, homológiai viszonyban állnak egymással. Az emberek különleges szabadidős tevékenységükkel definiálják és különítik el magukat másoktól. A kulturális rétegek közül a felső rétegek diktálják a szabályrendszert, az alsóbb rétegek ezt a kulturális minősítést többnyire elfogadják. Ez azt jelenti, hogy a legitimitás szférájába tartozó preferenciák és ismeretek hierarchikusan oszlanak el, más szóval a fogyasztási modellek hierarchikus rendszert alkotnak. ${ }^{4}$

Jürgen Zinnecker a fiatalokat vizsgálva Bourdieu elméletével egyetértve úgy véli, hogy a fiatalok a szülők társadalmi osztályhelyzete szerint szegmentálódnak. A felső rétegekre az ifjúkor meghosszabbítása, az idővel való ,,pazarló bánásmód” jellemző, ami azt jelenti, hogy sok időt kapnak arra, hogy kapcsolati hálójukat bővítsék, illetve különböző helyeken és helyzetekben kipróbálják magukat, tehetségüket. A csekély tőkével rendelkező, alsó osztálybeli fiatalok esetében az ifjúkor siettetésének a kényszere uralkodik, ami nem hagyja kibontakozni az ifjúságot. ${ }^{5}$ A vebleni szemlélet a társadalmi státuszkérdésre koncentrál, fontos szerepet tulajdonít a státus megőrzésnek, ahogy a bourdieu-i és a zinneckeri megközelítés is.

A felvázolt strukturalista magyarázatokat a hetvenes nyolcvanas évek kulturális fordulata következtében egyre inkább a kulturalista megközelítések váltották fel. Colin Campbell a modern fogyasztói éthoszt az aktív élvezetre és a megelégedettségre törekvéshez köti. Véleménye szerint nem az utánzás vagy a versengés motiválja az egyéneket a fogyasztásra, hanem az érzelmek által irányított élvezetkeresés mozgatja: ,,a modern fogyasztás olyan tevékenységnek tünik, melynek legjellemzőbb tulajdonsága a vágyak látszólag véget nem érő, telhetetlen hajszolása". ${ }^{6}$ Gábor Kálmán is hasonlóan vélekedik, amikor azt írja, hogy a korábbi kapitalizmusokat a szükösség, a korlátozott lehetőségek és az erös társadalmi hierarchia határozta meg, a bőség társadalmát a kényszer helyett az élmények keresése, átélése,

\footnotetext{
3 Baudrillard, Jean: A tárgyak rendszere. Budapest: Gondolat kiadó, 1987.

4 Bourdieu, Pierre: Distinction: A Social Critique of the Judgement of Taste. Harvard Univerity Press, 1984.

5 Zinnecker, Jürgen: A fiatalok a társadalmi osztályok terében. In: Gábor Kálmán: (szerk.): Civilizációs korszakváltás és ifjúság. Szeged: Szociológiai mühely, 1993. 5-28.

6 Campbell, Colin: A modern fogyasztói étosz rejtélye. Replika, 1996, 21-22. 117-137. 118.
} 
a lehetőségek tárháza jellemzi. ${ }^{7}$ David Muggleton szerint a fiatalok életében egy felfokozott individualizmus van jelen, és ebben kiemelt szerepet kap az önértelmezés, továbbá azt feltételezi, hogy a posztmodern szubkultúrákban egyre nehezebb fenntartani a szubkultúra határait, a stílusok közötti átjárások felületesebbé fognak válni, és ezáltal a szubkulturális kötődések szintén. ${ }^{8}$ Andy Bennett is amellett érvel, hogy a fogyasztói lét lehetőséget teremtett a fiataloknak arra, hogy elszakadjanak az osztályalapú identitásuktól, és a saját maguk által létrehozott identitással kísérletezzenek. ${ }^{9}$

A kilencvenes évek elején bekövetkezett ifjúsági korszakváltás során a kelet-európai fiatalok körében is meghatározóvá válik a fogyasztás, a fiatalság egyre nagyobb önállóságot vív ki magának. Ez a fajta önállóság újfajta értékrendet és kulturális mintát alakít ki, mely elsősorban fogyasztás- és szabadidő-orientált. ${ }^{10}$ Tanulmányunkban őket nevezzük ,mai fiataloknak”. Ezek a fiatalok meglehetősen nagy szabadsággal választhatják meg életstílusukat, viszont a fokozódó sokféleségben nehezebben igazodnak el. Megszünik az a fajta centrális világnézet, amely korábban a dolgok értelmezésében keretet adott. A modern társadalomban a gazdaság termelése együtt jár a társadalmi kockázatok termelésével, ${ }^{11}$ az élethelyzetek és életstílusok individualizálódnak, az egyének társadalmi pozícióját a fogyasztás jelöli ki. A fogyasztás nem egyszerủen az újratermelés funkcióját tölti be, hanem társadalomszervező erővé is lett. ${ }^{12}$ Azonban a fogyasztói ipar, a végbement individualizációs és globalizációs tendenciák átstrukturálták a fiatalok lehetőségeit a társadalmi egyenlőtlenségek rendszerében. Veres Valér az erdélyi fiatalokat vizsgálva azt találja, hogy a struktúra felső részéhez tartozó fiatalok inkább a globalizációval járó problémákkal szembesülnek, míg a struktúra alsó részéhez tartozó fiatalok problémái lokális jellegüek, és inkább a leszakadás veszélye fenyegeti őket. ${ }^{13}$

7 Gábor Kálmán: Magyar fiatalok a világkockázati társadalomban. Korunk 2009/2. 76-85.

8 Muggleton, David: Inside Subculture. The Postmodern Meaning of Style. Oxford: Berg, 2000.

9 Bennett, Andy: Szubkulturák vagy neo törzsek? A fiatalok, a stílus és a zenei ízlés közötti kapcsolat újragondolása. Replika, 2005/53. 127-145.

Ercsei Kálmán - Kiss Zita - Szabó Júlia: Fiatalok szabadidős fogyasztása, önállósodása és jövőképe a marosvásárhelyi Félsziget-vizsgálatok alapján. In: Kiss Tamás. - Barna Gergő (szerk.): Erdélyi magyar fiatalok. Összehasonlító elemzés. Kolozsvár: ISPMN - Kriterion Könyvkiadó, 2011. 233-260.; Gábor Kálmán - Veres Valér: Transformarea socială şi tineretul în Europa de Est. Situaţia tinerilor maghiari din România. In: Kiss Tamás - Barna Gergö Kozák Gyula (coord.): Tinerii maghiari din România. Dimensiuni comparative. Cluj Napoca: Ed. ISPMN - Ed. Kriterion, 2011. 39-56.

11 Beck, Ulrich: Mi a globalizáció? Szeged: Belvedere, 2005.

12 Hetesi Erzsébet: A fogyasztás szociológiája. In. Czagány László - Garai László (szerk.) A szociális identitás, az információ és a piac. Szeged, SZTE Gazdaságtudományi Kar Közleménye. JTAEPress, 2004. 267-281

13 Veres Valér: A fiatalok munkaerő-piaci helyzete, a társadalmi közérzet és a problémaérzékelés rétegspecifikus életérései. In: Kiss Tamás - Barna Gergő (szerk.) Erdélyi magyar fiatalok. Összehasonlitó elemzés. Nemzeti Kisebbségkutató Intézet. Kolozsvár, 2011. 55-85. 
Claire Wallace a fogyasztói kultúra terjedésére hívja fel a figyelmet, és azt mondja, hogy egyre nagyobb fogyasztási kényszer nehezedik a fiatalokra, ami jelentős strukturális változást eredményez. ${ }^{14} \mathrm{~A}$ kelet- és közép-európai fiatalok egyre inkább a fogyasztói stílusok tekintetében differenciálodnak, bár fogyasztási lehetőségeik igen egyenlőtlenek. Lynne Chisholm szerint a demográfiai és gazdasági változások, a technológia fejlődése módosítják az ifjúsági átmenetek szabályozó mechanizmusait. A fiatalokat fogyasztás- és szabadidő-orientáltság jellemzi, a fiatalok önálló társadalmi csoportja, rétege alakul ki: egy új ifjúsági kultúra. ${ }^{15}$

Megjegyzendő azonban, hogy ezek a folyamatok nem érvényesek általánosan, hanem társadalmi berendezkedések függvénye, sőt, az egyes társadalmakon belül is eltérően érvényesülnek. A kutatók felhívják a figyelmet a folyamat osztály/ rétegspecifikus jellegére, miszerint az ifjúsági korszakváltás nem vonatkozik mindenkire egyaránt, hanem eltérően érvényesül a fiatalok különböző szegmenseiben. E tekintetben kétféle forgatókönyvet látnak érvényesülni: az egyik az önállóság, a szabadidő, a mobilitás megnövekedésének forgatókönyve, a másik a leszakadó, társadalom alatti osztály munkanélküliségi forgatókönyve. ${ }^{16}$

Erdélyben a Félsziget-kutatások kapcsán jegyzi meg Veres Valér és Ercsei Kálmán, hogy a romániai fiatalok körében is olyan társadalmi folyamatok észlelhetők, amelyek egy „kettős forgatókönyvü” ifjúsági korszakváltás bekövetkeztére utalnak: a munkanélküliségi forgatókönyvhöz a társadalom alatti osztály újratermelődését, míg a szabadidős forgatókönyvhöz a középosztályosodást társítják. ${ }^{17}$ Az erdélyi magyar fiatalok körében a munkanélküliségi szcenárió és a szabadidő megnövekedésének forgatókönyve egyszerre érvényesül, és kialakul az ifjúság „kettészakadt” társadalma. ${ }^{18}$ Minél magasabb társadalmi státussal rendelkezik a származási család, annál nagyobb esélye van a fiatalnak arra, hogy a saját szabadidős szcenárióját élhesse meg, illetve minél alacsonyabb társadalmi státussal rendelkezik a származási család, annál valószínủbb, hogy a munkanélküliség forgatókönyve fog érvényesülni. Hasonló polarizációról írtam egy korábbi tanulmányomban: az erdélyi magyar fiatalok társadalmi struktúrában elfoglalt helyzete

14 Wallace, Claire: Ifjúság, munka és oktatás a posztkommunista Európában: út az individualizáció felé? Korunk, 1998/6. 5-12.

15 Chisholm, Lynne: Élesebb lencse vagy új kamera? In: Gábor Kálmán (szerk.): Civilizációs korszakváltás és ifjúság. Szeged: Szociológiai Mühely, 1993. 49-70.

16 Chisholm, 1993.

17 Veres Valér: Középosztályosodási tendenciák vizsgálata a marosvásárhelyi Fél-sziget Fesztivál résztvevői körében. In: Ercsei Kálmán - Veres Valér (szerk.) WEB Fesztiválok Ifjúsága. Kolozsvár: Cova-print,1-2, 2006. 35-47.; Ercsei Kálmán: Félsziget Fesztivál ifjúsága: Fesztiválok ifjúsága? Az iskolázottság és továbbtanulás összehasonlító vizsgálata az ifjúsági korszakváltás kontextusában. In: Ercsei Kálmán - Veres Valér (szerk.): WEB. Fesztiválok Ifjúsága. Kolozsvár: Cova-print, 2006. 47-63.

18 Ercsei, 2006., Gábor Kálmán: Globalizáció és korszakváltás. In: Gábor Kálmán - Jancsák Csaba (szerk.): Ifjúsági korszakváltás. Ifjúság az új évezredben. Szeged: Belvedere, 2004. 28-72. 
olyan többdimenziós térben tagozódik, melyben egy széles réteg, a „passzívak” csoportja esetében a kulturális fogyasztás mértéke meglehetősen alacsony, vagyis a fogyasztói miliők alatt helyezkednek el. ${ }^{19}$

A kulturális fogyasztás vizsgálatának tekintetében meg kell említenünk a kulturális mindenevőség fogalmát, ami a Peterson illetve Simkus és Peterson és Kern szerzőpárosok nevéhez füződik, akik a zenei ízlést vizsgálva állapítják meg, hogy egyfajta történelmi váltás vette kezdetét. A „kultúrsznobizmus”, amire egyfajta exkluzivitás volt jellemző, átalakul egy jóval nyitottabb, mindenevő stílussá, ami azt jelenti, hogy a magas kultúra és a populáris kultúra közötti választóvonal átjárhatóbbá válik. ${ }^{20}$ Kristóf és Kmetty szintén a zenei ízlést helyezik a fókuszba, és arra keresik a választ, hogy a magyar társadalomban kimutatható-e a kulturális mindenevőség jelensége. ${ }^{21}$

Chan és Goldthorpe nemcsak a zenei ízlés tekintetében, hanem a különböző kulturális rendezvényeken való részvétel alapján vizsgálják a kulturális fogyasztás és társadalmi rétegződés kapcsolatát. ${ }^{22} \mathrm{~A}$ kulturális mindenevők általában a magas státusú egyének, magasan iskolázottak, inkább urbánus környezetben élnek és főleg nők. ${ }^{23}$ Egy későbbi cikkükben azt is sugallják, hogy a „mindenevő ízlés” széles, eklektikus kulturális ízlés, amely a társadalom felsőbb rétegeire jellemző, a tolerancia és nyitottság növekedését jelképezi mind esztétikai mind társadalmi szempontból. ${ }^{24}$

Az „omnivore-univore” paradigma érvényességét magyarországi adatokon is vizsgálták. ${ }^{25}$ A magyar társadalom fogyasztói csoportjai között is jelen van a kul-

19 Szabó Júlia: Kulturális szegmentáció az erdélyi magyar fiatalok körében. Socio.hu, 2018/3. 62-79.

20 Peterson, Richard A. - Simkus, Albert: How musical tastes mark occupational status groups. In: Lamont, M. - Fournier, M. (ed.) Cultivating differences: Symbolic boundaries and the making of inequality. Chicago: University of Chicago Press, 1992. 152-186.; Peterson, Richard A. - Kern, Roger: Changing Highbrow Taste: From Snob to Omnivore. American Sociological Review, 1996. 61 (5). 900-907. http://dx.doi.org/10.2307/2096460.

21 Kristóf Luca - Kmetty Zoltán: Szereti Ön Vivaldit? Zenei ízlés és társadalmi státusz. Szociológiai Szemle, 2019/2. 49-67.

22 Chan Tak Wing - Goldthorpe, H. John: The Social Stratification of Theatre, Dance and Cinema Attendance. Cultural Trends, 2005. Vol. 14(3). No.55, 193-212 http://users.ox.ac. uk/ sfos0006/papers/ct2005.pdf; Chan, Tak Wing - Goldthorpe, H. John: Social stratification of Cultural Consumption. The visual arts in England. Poetics, 2007. 35 (2-3). 168-190. http:// dx.doi.org/https://doi.org/10.1017/cbo9780511712036.008.; Chan, Tak Wing - Goldthorpe, H. John: Social Status and Cultural Consumption. In: Chan, T. W. - Goldthorpe, J. (szerk.) Social Status and Cultural Consumption. Cambridge University Press, 2010. 1-28.

Chan, Tak Wing: Understanding Cultural Omnivores: Social and Political Attitudes, 2013. Elérhető: http://users.ox.ac.uk/ sfos0006/papers/att3.pdf Chan-Goldthorpe 2010; Chan, 2013.

25 Bukodi Erzsébet: Social stratification and cultural participation in Hungary: a post-communist pattern of consumption? In: Chan, Tak Wing - Goldthorpe, John (ed.): Social Status and Cultural Consuption. Cambridge University Press, 2010. 139-168.; Sági Matild: Kulturális 
turális mindenevőség jelensége. Egyetértenek abban, hogy a modern társadalomban a kulturális fogyasztás egyre inkább „mindenevő” jelleget ölt magára, és ezek csoportja magas státusú egyénekböl áll, magas iskolai végzetséggel, illetve elönyös családi háttérrel rendelkeznek.

Bár a mindenevőség első látásra valamiféle kulturális demokrácia jele lehet, valójában nem kérdőjelezi meg a Bourdieu által felvetett kulturális megkülönböztetési és legitimációs mechanizmusok helytállóságát. A mindenevőség megjelenéséhez a kulturális hierarchiák fenntartására van szükségük, nem pedig összeomlásukra. ${ }^{26}$ Több kutatás is igazolta, hogy a mindenevőség társadalmilag rétegzett jelenség, amely horizontálisan és vertikálisan egyaránt megkülönbözteti a társadalmi csoportokat. $^{27}$

Elemzésünk során a társadalmi struktúra és a szabadidős fogyasztás viszonyára fókuszálunk a határon túli magyar fiatalok körében. A fogyasztás társadalomalakító funkcióját vizsgáljuk, nevezetesen azt, hogy:

(1) milyen tényezők befolyásolják a szabadidős fogyasztást a Kárpát-medence régióiban?

(2) hogyan hatnak az életstílusra, a kulturális fogyasztási szokásokra a társadalmi státus összetevői, mint az iskolázottság, a foglalkozás, illetve a demográfiai jellemzők, mint a nem és az életkor?

(3) milyen mértékben igaz az, hogy a fiatalok és köztük a kelet-európai fiatalok is egyre inkább a világtársadalom részeseivé válnak?

\section{Fiatalok szabadidős mintázatai a Kárpát-medencében}

Az elemzés során a GeneZYs 2015-ös Kárpát-medencei ifjúságszociológiai felmérés adatait használtuk fel, ami 15-29 éves külhoni magyar fiatalok megkérdezésével készült reprezentatív kutatás (1000 erdélyi, 700 felvidéki, 500 vajdasági és 500 kárpátaljai). A kulturális szegmentációt a különböző szabadidős tevékenységeken való részvétel gyakorisága alapján határoztuk meg. A szabadidős szokásokat egy 27 elemből álló kérdéssor tárta fel, és mindegyik tevékenységet 1-től 10-ig terjedő skálán kellett értékelniük a fiataloknak, annak függvényében, hogy milyen gyakran

szegmentáció: „mindenevők”, „válogatósak”, „egysíkúak” és „nélkülözők”? Az „omnivore-univore” modell alkalmazhatósága Magyarországon. In: Kolosi Tamás - Tóth István György (szerk.): Társadalmi riport. Budapest: Tárki, 2010. 288-311.

26 Hanquinet, Laurie. Inequalities: when culture becomes a capital. In: O`Brien, D. - Miller, T. Durrer, V. (szerk.): The Routledge Handbook of Global Cultural Policy. London: Routledge, 2017.

27 Savage, Mike - Devine, Fiona - Cunningham, Niall - Taylor, Mark - Li, Yaojun - Hjellbrekke, Johs - Le Roux Brigitte - Friedman, Sam - Miles, Andrew: A New Model of Social Class? Findings from the BBC's Great British Class Survey Experiment. Sociology, 2013. 47 (2). 219-250.; Sági, 2010.; Bukodi, 2010. 
végzik az alábbi tevékenységeket (1-soha és 10-nagyon gyakran). A fogyasztói csoportok meghatározásához a klaszterelemzés módszerét használtuk.

Első lépésben a vizsgált tevékenységtípusokat a Barna Gergö ${ }^{28}$ által is használt csoportosítás szerint fogjuk bemutatni, melyekre átlagokat számoltunk: a kultúraorientált-, médiaorientált, mozgás és szépítkezésorientált, illetve társaságorientált szabadidős tevékenységekről esik majd szó.

Az első csoportba a kultúraorientált szabadidős tevékenységeket soroltuk. ${ }^{29}$ Ezek alatt egyrészt a magas kulturális tevékenységeket értjük, amelyek elsősorban a magas társadalmi státuszú csoport tagjai számára nyújtanak kikapcsolódási, szórakozási, művelődési lehetőséget, ${ }^{30}$ mint a színházba, hangversenyre, operába járás. Másrészt olyan szimbolikus tevékenységeket, amelyek a kreativitás, eredetiség kritériumainak felelnek meg, mint például a zenélés, festés, rajzolás, blog/versírás, illetve a könyvolvasás, a könyvárba járás és a képzéseken való részvétel. A táncházba járást szintén a kulturális tevékenységekhez soroltuk. A blog mint internetes napló is ebbe a kategóriába került, mert a hangsúly az íráson/alkotáson van, és nem az internethasználat gyakoriságán (lásd az 1. ábrát).

A leggyakrabban végzett szabadidős tevékenység egész Kárpát-medencében az olvasás; a legmagasabb értéket a Vajdaság és Felvidék (4,9) mutatja, majd Erdély $(4,4)$ és ezt követően Kárpátalja $(4,2)$. A második legkedveltebb szabadidős tevékenység a zenélés/festés/rajzolás, mely terén szintén a vajdasági fiatalok a legaktívabbak, de hasonlóképpen az erdélyi fiatalok is, és ezt követően a kárpátaljai és felvidéki fiatalok.

A magaskultúra színtereit vizsgálva azt láthatjuk, hogy hangversenyre, illetve operába szinte soha nem járnak a fiatalok. Kárpátalján és Felvidéken a legmagasabb azon fiatalok száma, akik nem látogatják a magaskultúra olyan helyszíneit, mint az opera és a hangverseny. A korábbi, Mozaik 2001-es vizsgálathoz hasonlóan és az ezt követő 2016-os ifjúsági felmérés szerint is a két legkevésbé látogatott kulturális rendezvény az opera és a komolyzenei hangverseny. ${ }^{31}$

A magaskultúrát megjelenítő további színtér, a színház látogatása a korábbi évekhez viszonyítva szintén csökkenő tendenciát mutat. A Kárpát-medence régióiban a vajdasági és az erdélyi fiatalok járnak a leggyakrabban színházba, legkevésbé

28 Barna Gergő: Szabadidő, kultúra, média, internet - román és magyar fiatalok fogyasztási szokásai. In: Kiss Tamás - Barna Gergö (szerk.): Erdélyi magyar fiatalok. Összehasonlitó elemzés. Kolozsvár: Nemzeti Kisebbségkutató Intézet, 2011. 91-151.

Barna, 2011.

30 Fekete Mariann: eIDÖ, AVAGY A SZABADIDÖ BEHÁLÓZÁSA. Generációs kultúrafogyasztás a digitális korban. Szeged: Belvedere Meridionale, 2018.

31 Szabó Júlia - Hires-László Kornélia: Régi és új kultúra In: Székely Levente (szerk.): Magyar Fiatalok a Kárpát-medencében. Magyar Ifjúság Kutatás 2016, Budapest, 2018. 317-353. 332. 


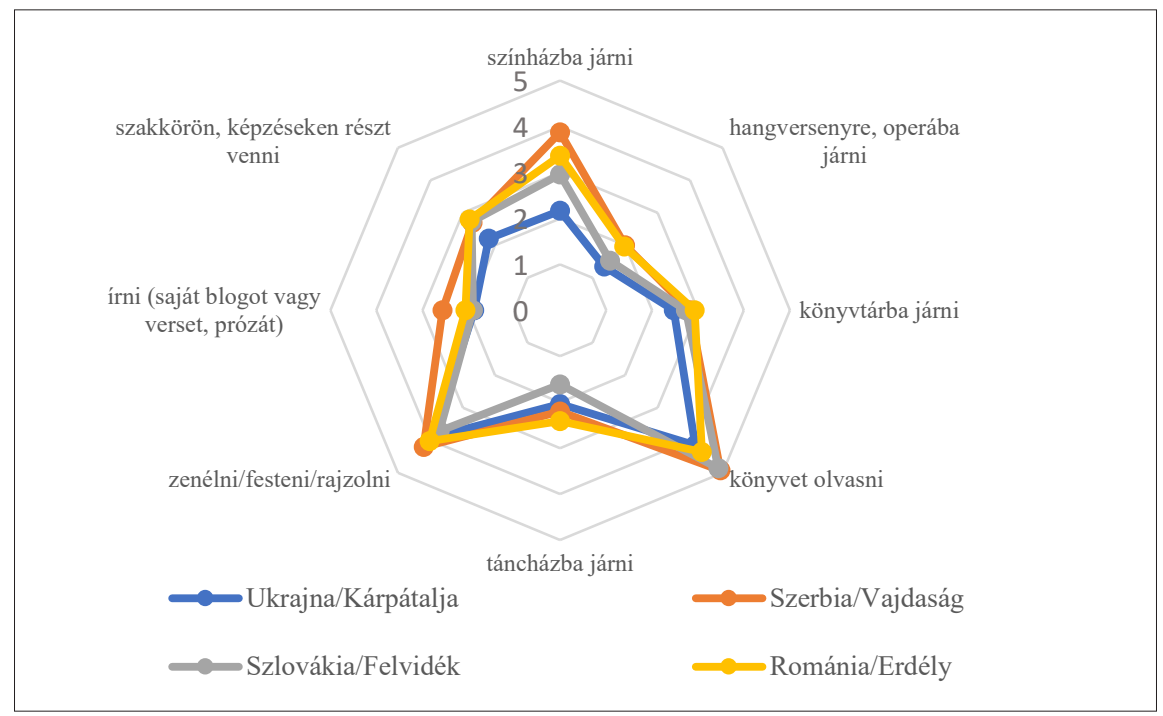

1. ábra. Kultúraorientált szabadidős tevékenységek - átlagok

pedig a kárpátaljai fiatalok. Ez a tendencia szintén összecseng a 2016 felmérésben mért eredményekkel. ${ }^{32}$

A táncházba, könyvtárba járás, illetve a vers/blogírás és képzéseken való részvétel kevés teret kap a fiatalok életében, szinte kivétel nélkül mindegyik országban az átlagok nagyon alacsony értéket mutatnak, de a színházhoz hasonlóan ez a három szabadidős tevékenység is a vajdasági és az erdélyi fiatalok körében a leggyakoribb (1. ábra).

A médiaorientált tevékenységeken a médiafogyasztást és az internethasználatot értjük. Ezt vizsgálva egy sokkal aktívabb kép rajzolódik ki (lásd a 2. ábrát). Azt láthatjuk, hogy a facebookozás lett az egyik leggyakoribb tevékenység, a tévézést is megelőzi, ami évekig első helyen szerepelt a fiatalok életében. A felvidéki, erdélyi, illetve a vajdasági értékek a mért tízes skálán 7,3, 7,2 és 7,1 átlagot érnek el. Kárpátalján 6,2-es átlagot mértünk, tehát egy egységnyivel kevesebbet facebookoznak a kárpátaljai fiatalok. Hasonlóan magas értéket (szintén 7-es átlagot) mutat mindenik régióban az otthon való filmnézés is, Kárpátalján ez esetben is kisebb az érdeklődés.

A tévézésre szánt idő jelentősen csökkent a digitális média hatására, a Vajdaságban a számolt átlagok a tévénézésre 2 egységnyivel kisebb értéket mutatnak,

32 Felvidéken és Kárpátalján a fiatalok több mint 60 százaléka szinte soha nem volt színházban. Erdélyben a fiatalok fele válaszolta azt, hogy szinte soha nem volt színházban, Vajdaságban pedig a fiatalok csupán 35 százaléka. L. Szabó - Hires, 2018. 333. 


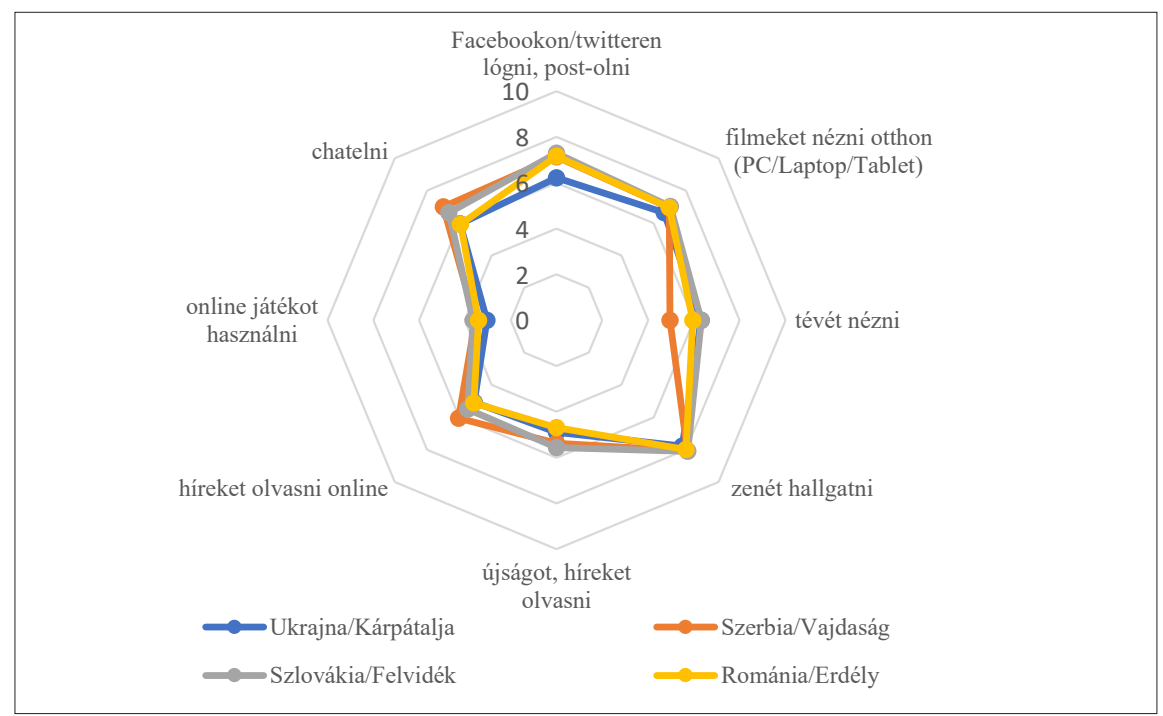

2. ábra. Médiaorientált szabadidős tevékenységek - átlagok

mint a facebokozás esetében (5), a többi három régióban pedig egy egységgel kevesebbet néznek tévét a fiatalok.

A hírek olvasása ötös átlagértéket mutat, mind papíralapon, mind pedig az online felületen való tájékozódás terén. A Vajdaságban és Felvidéken ebben a tekintetben kissé nagyobb az aktivitás.

A chatelés szintén nagy teret kap a fiatalok szabadidö-eltöltésében, és meszszemenően meghaladja a kultúraorientált fogyasztói csoportban levő leggyakoribb tevékenységet - a könyvolvasást - is, ami átlagban ötös értéket kapott. A chatelés a Vajdaságban (7) és Felvidéken $(6,6)$ mutat a legnagyobb értéket, majd Erdélyben $(5,9)$ és Kárpátalján (6) (2. ábra).

A mozgásorientált és szépitkezésorientált tevékenységeken a jó közérzet és a minőségi élet megteremtését szolgáló rekreációt értjük. A sportolással és a szépítkezéssel kapcsolatos szabadidős tevékenységeket soroltuk ebbe a csoportba. (lásd a 3. ábrát) A leggyakrabban végzett tevékenység a természetben való kirándulás, illetve a sportolás-kocogás. Itt is, mint korábban, nagyobb aktivitást láthatunk az erdélyi, illetve a felvidéki fiatalok körében. Ezek a tevékenységek öt fölötti átlagot mutatnak. A legkevésbé gyakorolt szabadidős tevékenységek az uszodába, szaunába, szoláriumba, illetve a fitness- és konditerembe járás. A szépségorientált tevékenységek, mint kozmetikushoz vagy fodrászhoz járás szintén alacsony gyakoriságot mutatnak, a fiatalok ritkábban végzik ezeket a tevékenységeket (3. ábra).. 


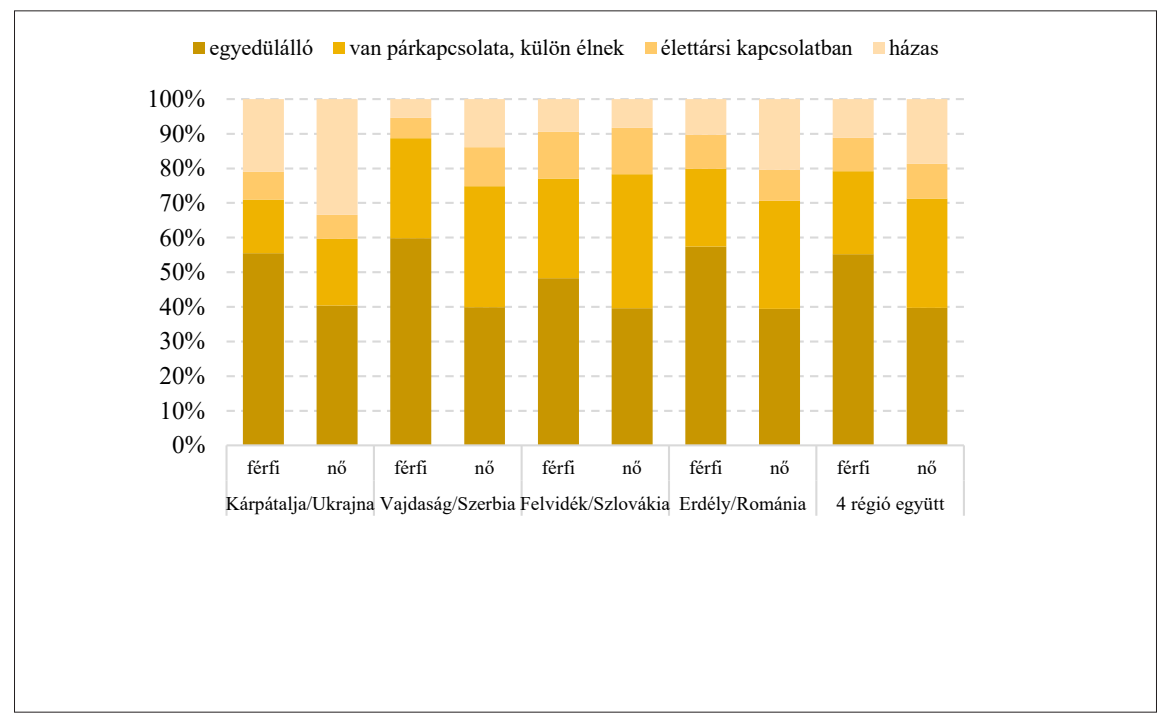

3. ábra. Mozgás- és szépitkezésorientált szabadidös tevékenységek - átlagok

Végül a társaságorientált tevékenységeket vizsgáltuk, amelybe a szórakoztató, társaságot igénylő tevékenységeket soroltuk. A 4-es ábra alapján a legmagasabb értéke a barátokkal való együttlétnek van (Vajdaság 7,8; Felvidék 7,5; Erdély 7,4; Kárpátalja 6,2). Az átlagok alapján a vajdasági fiatalok a legaktívabbak, szorosan követi öket a felvidéki és erdélyi ifjúság. (lásd. 4. ábra). A kárpátaljai fiatalok ezen tevékenységtípusokban is kissé passzívabbnak mutatkoznak a többi régió fiataljaihoz hasonlítva (4. ábra).

Amikor a fiatalok szabadidős fogyasztásának időbeni alakulását vizsgáljuk, és ezeket összehasonlítjuk a korábbi Mozaik 2001 felmérés eredményeivel, majd az ezt követő Ifjúság 2016-os felmérés adataival, módszertani nehézségekbe ütközünk, ugyanis a szabadidős szokásokat a különböző kutatások, különböző kérdéstípusokkal vizsgálták ${ }^{33}$. Ennek ellenére a tendenciák jól megragadhatók, melyekre a fentiek során utaltunk is.

33 A szabadidős tevékenységek gyakoriságának a felméréséhez a kutatások különböző típusú Likert skálákat alkalmaztak. A Mozaik 2001-e felmérés 12 szabadidős tevékenységet mért az alábbi skálával:1 (1 hónapon belül), 2 (1-2 hónapja), 3 (4-6 hónapja), 4 (ennél régebben) 9 (soha). A GeneZYs 2015-ös felmérés 27 itemet mért egy 1-től 10-ig terjedő skálán, ahol az 1-es azt jelentette, hogy Soha, a 10-es meg azt, hogy Nagyon gyakran. A Magyar Ifjúság 2016 kutatás pedig 15 szabadidős tevékenységet mért, ahol a skála értékei az alábbiak voltak: 1 (hetente többször), 2 (hetente egyszer), 3 (havonta többször), 4 (2-3 havonta), 5 (évente többször), 9 (szinte soha). 


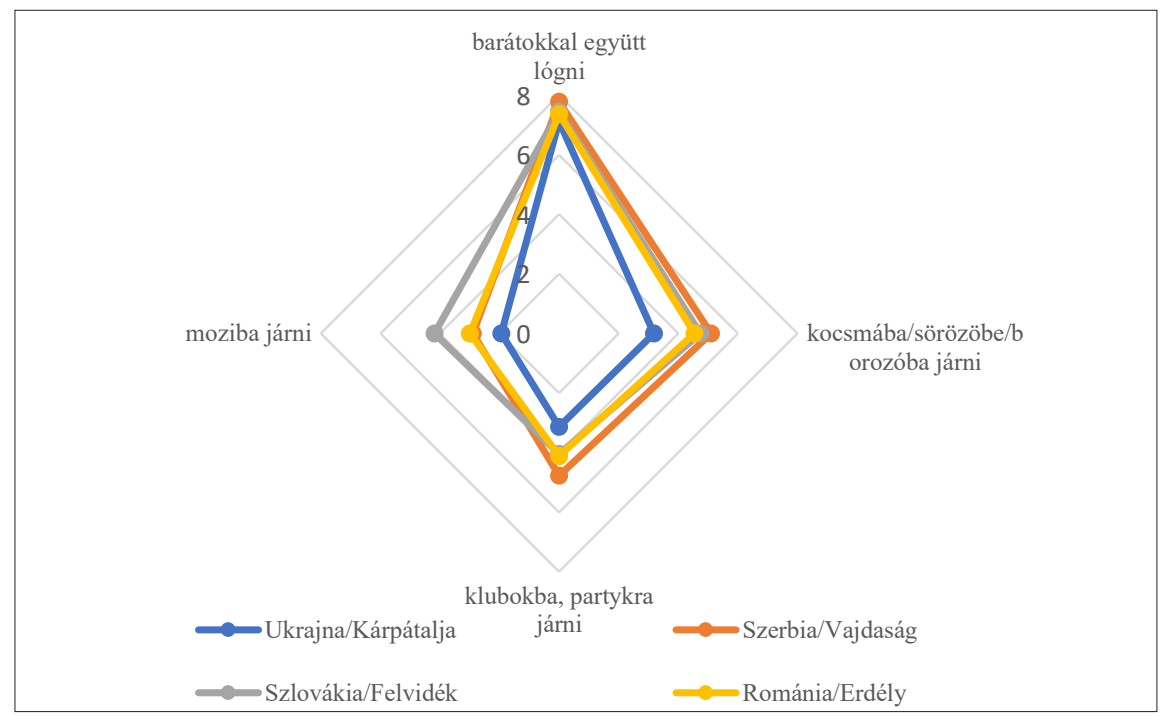

4. ábra. Társaságorientált szabadidös tevékenységek - átlagok

Továbbá az is figyelemre méltó, hogy a társadalmi változások függvényében bizonyos színterek átalakultak a szabadidős palettán, illetve újak jelentek meg. A 2001-es felmérésben a Kárpát-medence mindegyik régiójában a fiatalok leggyakrabban látogatott színtere a diszkó volt, ez a 2015-ös, illetve a 2016-os kérdőívben már nem került lekérdezésre, ennek helyét átvették a klubok, partik, illetve a könnyüzenei koncerteken való részvétel. Hasonlóképpen a facebookozás és a chatelés a 2001-es felméréskor még nem volt releváns.

Összességében azt mondhatjuk, hogy a három leggyakoribb szabadidős tevékenység a határon túli magyar fiatalok körében a zenehallgatás, a barátokkal együtt töltött idő és a facebookozás. Az összes régióban az internet, pontosabban a Facebook átvette a domináns szerepet a tévézéssel szemben. ${ }^{34}$ A kulturális terek közül a leglátogatottabb helyszín a színház és a könyvesboltok, ahova az erdélyi és a vajdasági fiatalok járnak el a leggyakrabban. Az opera és a hangverseny, a korábbi 2001-es, illetve a későbbi 2016-os felmérések eredményeivel összhangban, a legritkább szabadidős tevékenységnek számít.

A kárpátaljai kutatók is a kulturális élet szegénységére hívják fel a figyelmet a Mozaik 2001-es felmérés eredményeinek bemutatásakor, ${ }^{35}$ amely föleg a vidéken élökre jellemzö, azonban ez a jellegzetesség most is megállapítható, ugyanis az

34 Hires - Szabó, 2018.

35 Csernicskó István - Soós Kálmán. Kárpátalja. In Szabó Andrea - Bauer Béla - Laki László - Nemeskéri István (szerk.). Mozaik2001 Gyorsjelentés, Nemzeti Ifjúságkutató Intézet. 91-137. 
országokat elemezve továbbra is a kárpátaljai fiatalokra jellemző a legpasszívabb, legszegényesebb szabadidőeltöltés.

Ezzel szemben a vajdasági fiatalok, akik a 2001-es felmérés során inkább a könnyed szórakozást részesítették előnyben, a 2015-ös és a 2016-os felmérés adatai alapján egy sokkal aktívabb, sokszínűbb szabadidős fogyasztást tanúsítanak. Ez feltehetően a kulturális és szabadidőipar bővülésének is betudható.

\section{Fogyasztói csoportok a Kárpát-medencében}

Ahhoz, hogy pontosabb képet kapjuk a határon túli magyar fiatalok kultúrafogyasztásáról, első lépésben K-means klaszterelemzés segítségével fogyasztói szegmenseket határoztunk meg és ezt követően ezeket a csoportokat vizsgálatuk.

A ,,mindenevők ${ }^{36}$ " csoportjának neveztük el azokat a fiatalokat, akik mindegyik szabadidős tevékenységben magas aktivitást mutattak. Ezek a fiatalok nagy gyakorisággal vesznek részt mind a kultúra-, mind a média-, mind pedig a társaság- és mozgásorientált tevékenységekben. A mindenevők csoportjában mindegyik szabadidős tevekénység a legmagasabb gyakoriságot mutatta, kivéve a tévénézést az erdélyi és a vajdasági fiatalok esetében. A mindenevők csoportja Erdélyben a legnagyobb.

A , magaskultúra-orientáltak” csoportjának neveztük el azt a klasztert, melyben a színházba és az operába járás, a komolyzenei hangversenyen való részvétel magas gyakoriságot mutattak, és az olyan kreatív tevékenységek is, mint a zenélés, festés, rajzolás, írás (saját blogot vagy verset), a könyvtárba járás, illetve a könyvolvasás. A régiókat összevetve a felvidéki fiatalok csoportja a legszámottevőbb és a kárpátaljai fiatalok a legkevésbé „magaskultúra-orientáltak”.

A ,, screenagerek ${ }^{, 37}$ klaszterbe azok a fiatalok tartoznak, akiknek szabadidős tevékenységük nagyon szorosan kapcsolódik az internet, illetve a képernyők világához. Nagy arányban aktív Facebook-felhasználók. Jellemző rájuk, hogy otthon néznek filmeket a számítógépen, zenét hallgatnak és chattelenek, illetve elég gyakori tevékenységként jelenik meg az online játékok használata is. Az úgynevezett magaskultúrát megjelenítő tevékenységek, mint a színház, az opera, nem vagy kevésbé jellemző erre a csoportra. A „screenegerek” csoportja Kárpátalján a legnagyobb, a fiatalok 34 százaléka tartozik ebbe a csoportba.

A negyedik klaszter a „passzívak” csoportja, melyen belül a fö tevékenység elsősorban a zenehallgatás és a tévénézés, illetve barátokkal való együtt lógás.

36 Az „omnivore-univore”, azaz a kulturális mindenevőség fogalma Peterson - Kern (1996), Peterson - Simkus (1992), Chan - Goldthorpe (2005, 2006) szerzőpárosokhoz füződik.

37 Faktoranalízis módszerével Veres (2011) az erdélyi magyar fiatalok körében kulturális fogyasztás tekintetében három csoportot azonosít: a screenagerek (20,5\%), a magaskultúra-fogyasztók (19,7\%) és klubkultúra-fogyasztók (17,5\%) csoportját. 


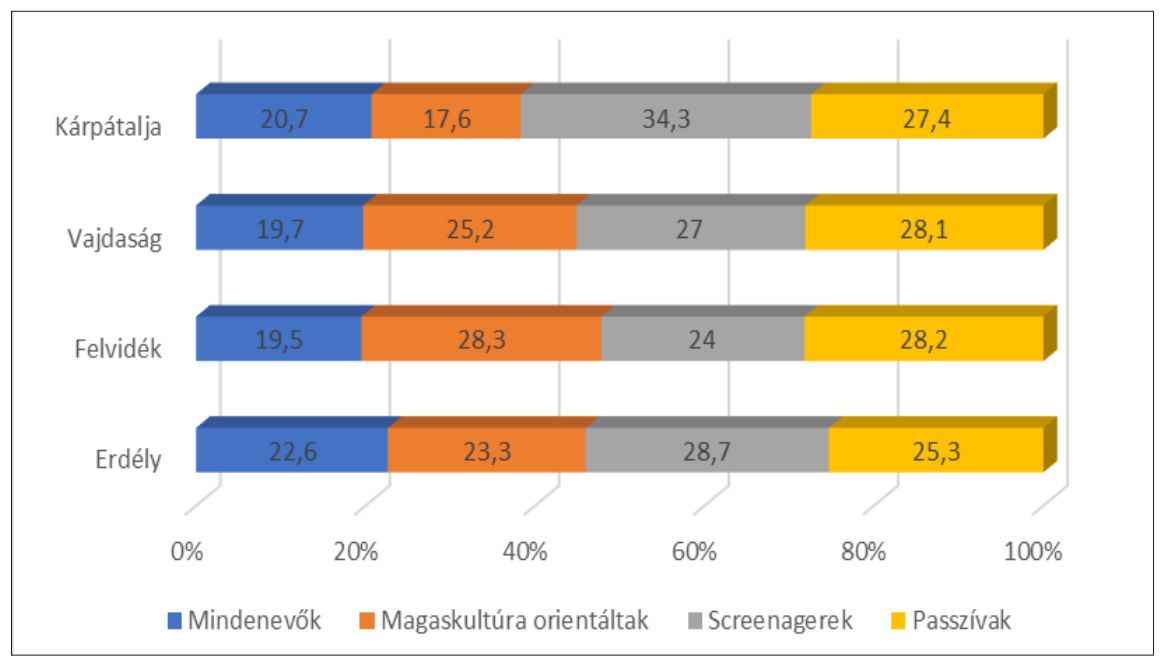

5. ábra. Fogyasztói csoportok - klaszterek (százalékok)

Kis arányban még jellemző a csoportra a facebookozás, illetve a laptopon való filmnézés, azonban minden más szabadidős tevékenység messze alulmarad a többi klasztereken belül folytatott gyakoriságától. Azok a fiatalok, akik ebbe a csoportba tartoznak, valamennyi szabadidős tevékenységet meglehetősen ritkán végzik. A régiókat összehasonlítva az erdélyi magyar fiatalok a legkevésbé passzívak (5. ábra).

Második lépésben az így kialakított fogyasztói csoportok társadalmi-demográfiai hátterét elemezzük a logisztikus regresszió módszerével. Azt vizsgáljuk, hogy milyen tényezők befolyásolják az egyes csoportokba való bekerülést. Mindegyik határon túli régió esetében négy magyarázó változót vontunk be az elemzésbe: az apa iskolai végzettsége és foglalkozása, illetve a megkérdezett neme és életkora. A településtípust mint magyarázó változót kihagytuk regressziós elemzésből, ugyanis a kereszttábla eredményei alapján (lásd a mellékleteket) csupán Erdélyben és Kárpátalján találtunk szignifikáns összefüggést a településtípus és a csoporthovatartozás között.

Minden egyes csoportba való tartozás magyarázatára egy külön regressziós modellt futtattunk le. A modellek függő változói a klasztercsoportok („screenagerek”, „magaskultúra.orientáltak”, „mindenevők”, „passzívak”) referenciaértékeit pedig az adott csoportba nem tartozó összes többi személy jelenti.

A logisztikus regressziós modellek értékeit az 1., 2., 3. és 4. táblázatok foglalják össze, melyeknek együtthatói úgy értelmezhetők, hogy a referenciakategóriához képest, amelyet a táblázat alján tüntettünk fel, hányszor nagyobb az esélye egy 
fiatalnak arra, hogy inkább a függő változó által jellemzett csoportba tartozzon, mint abból kimaradjon.

1.táblázat. Az egyes kulturális csoportokba való tartozást befolyásoló tényezők. Logisztikus regressziós modellek együtthatóinak exponenciális értékei, Exp (b) „Mindenevök”

\begin{tabular}{lllll}
\hline Magyarázó változók & Erdély & Kárpátalja & Vajdaság & Felvidék \\
\hline Apa iskolai végzettsége & & & & \\
\hline Alapfokú & $0,278^{* *}$ & 0,438 & 0,981 & 1,631 \\
\hline Középfokú & 0,695 & 1,537 & 1,231 & 1,304 \\
\hline Apa jelenlegi foglalkozása & & & & \\
\hline $\begin{array}{l}\text { Beosztott, alkalmazott (nem } \\
\text { közszférában vagy közszférában) }\end{array}$ & $2,543^{* *}$ & 0,708 & 0,965 & 1,625 \\
\hline Vezetö beosztású & $2,561^{*}$ & 0,442 & 1,258 & $7,608^{* *}$ \\
\hline Alkalmi munkából él meg & 0,757 & 0,544 & 0,395 & 0,000 \\
\hline Egyéni vállalkozó, társtulajdonos & $3,552^{* *}$ & 1,218 & 1,226 & $2,070^{*}$ \\
\hline Korcsoport & & & & \\
\hline 15-19 évesek & $2,909^{* *}$ & $4,746^{* *}$ & 1,331 & 1,255 \\
\hline 20-24 évesek & $1,776^{*}$ & $2,133^{*}$ & 0,686 & 0,899 \\
\hline Nem & \multicolumn{5}{l}{} \\
\hline Férfi & $0,383^{* *}$ & $0,508^{* *}$ & 1,016 & $0,320^{* *}$ \\
\hline Konstans & 0,175 & 0,197 & 0,215 & 0,307 \\
\hline Nagelkerke R Square & 0,186 & 0,197 & 0,039 & 0,163 \\
\hline
\end{tabular}

Referenciakategóriák: Felsőfokú végzettség, Egyéb (nyugdíjas, háztartásbeli- inaktív), 25-29 évesek, nő $* \mathrm{p}<0,05 ; * * \mathrm{p}<0,01$

A „mindenevők” csoportját vizsgálva az 5. ábra alapján az látható, hogy a vizsgált régiók közül Erdélyben vannak a legtöbben „mindenevők”, ők azok a fiatalok, akik a tévénézés kivételével mindegyik szabadidős tevékenységben a legaktívabbak.

A logisztikus regresszió együtthatói Erdélyben azt mutatják, hogy mindegyik magyarázó változó között szignifikáns összefüggés van. Az apa iskolai végzettségét vizsgálva az alapfokú végzettségüeknek kisebb esélye van $(1 / 0,278=3,6$-szoros) a „mindenevők” csoportjába való kerülésre. Az életkor is szignifikáns hatással van a csoporthovatartozásra, a 25-29 évesekhez viszonyítva háromszor nagyobb valószínüséggel tartoznak a 15-19 évesek ebbe a csoportba és közel kétszer nagyobb valószínűséggel a 20-24 évesek. A nemzetközi szakirodalommal összhangban a „mindenevők” inkább nők, ${ }^{38}$ azaz a nők esélye $1 / 0,383=2,61$-szeres a fér-

38 Chan, 2010. 
fiakéhoz képest ahhoz, hogy ide tartozzanak. Foglalkozás szerint, azok a fiatalok, akiknek az apja egyéni vállalkozó, közel négyszer nagyobb eséllyel tartoznak a mindenevők csoportjába, illetve háromszor nagyobb eséllyel azok, akiknek az apja vezető pozíciót tölt be, szemben azokkal, akiknek az apja inaktív. A kárpátaljai „,mindenevők” csoportjának társadalmi demográfiai háttere abban mutat hasonlóságot, hogy szintén inkább a nők vannak fölülreprezentálva, a nők esélye $1 / 0,508=1,96$-szeres. Korcsoport szerint pedig szintén az erdélyihez hasonló tendenciát látunk, ötször nagyobb eséllyel vannak a 15-19 évesek, mint az idősebb, 25-29 éves korosztály. Apa iskolai végzetsége és foglalkozása tekintetében nincs szignifikáns összefüggés.

A vajdasági fiatalok körében a „mindenevők” nem jellenek meg annyira markánsan, mint az erélyi fiatalok esetében, a magyarázott változók és a csoporthovatartozás tekintetében nem találtunk szignifikáns összefüggéseket. Felvidéken szintén nagyobb eséllyel van jelen a fiatalabb korosztály. Az apa iskolai végzettsége nem mutat szignifikáns összefüggést, viszont foglalkozás szerint közel négyszer nagyobb eséllyel tartoznak az egyéni vállalkozók gyerekei ebbe a csoportba, illetve háromszor nagyobb eséllyel azok, akik alkalmazottak, szemben az inaktívakkal.

2. táblázat. Az egyes kulturális csoportokba való tartozást befolyásoló tényezők. Logisztikus regressziós modellek együtthatóinak exponenciális értékei, Exp (b) „Magaskultúra-orientáltak”

\begin{tabular}{|c|c|c|c|c|}
\hline Magyarázó változók & Erdély & Kárpátalja & Vajdaság & Felvidék \\
\hline \multicolumn{5}{|l|}{ Apa iskolai végzettsége } \\
\hline Alapfokú & $0,117^{* *}$ & 0,513 & $0,279^{* *}$ & 1,631 \\
\hline Középfokú & $0,405^{* *}$ & 0,817 & $0,470^{*}$ & 1,304 \\
\hline \multicolumn{5}{|l|}{ Apa jelenlegi foglalkozása } \\
\hline $\begin{array}{l}\text { Beosztott, alkalmazott (nem köz- } \\
\text { szférában vagy közszférában) }\end{array}$ & 0,716 & 0,664 & 0,988 & 1,625 \\
\hline Vezető beosztású & 0,713 & 2,377 & 0,999 & $7,608^{* *}$ \\
\hline Alkalmi munkából él meg & 0,499 & $0,199^{* *}$ & 1,555 & 0,000 \\
\hline Egyéni vállalkozó, társtulajdonos & 1,141 & 0,557 & 1,294 & $2,070^{*}$ \\
\hline \multicolumn{5}{|l|}{ Korcsoport } \\
\hline 15-19 évesek & $0,463^{* *}$ & 0,560 & 1,402 & 1,255 \\
\hline 20-24 évesek & 1,050 & 0,601 & 1,283 & 0,899 \\
\hline \multicolumn{5}{|l|}{$\mathrm{Nem}$} \\
\hline Férfi & 0,875 & $0,437^{* *}$ & 0,695 & $0,320^{* * *}$ \\
\hline Konstans & 1,081 & 0,813 & 0,648 & 0,307 \\
\hline Nagelkerke R Square & 0,124 & 0,136 & 0,048 & 0,163 \\
\hline
\end{tabular}

Referenciakategóriák: Felsőfokú végzettség, Egyéb (nyugdíjas, háztartásbeli- inaktív), 25-29 évesek, nő ${ }^{*} \mathrm{p}<0,05 ;{ }^{* *} \mathrm{p}<0,01$. 
A ,magaskultúra-orientáltak” csoportjába azok a fiatalok tartoznak, akik fokozott érdeklődést mutatnak a magaskultúra iránt, és ugyanakkor más kultúraorientált tevékenységekben is aktívak.

A magyarázó változók közül Erdélyben az életkor és az apa iskolázottsága differenciál, miszerint a felsőfokú végzettséggel rendelkező apák gyerekei nagyobb eséllyel tartoznak ebbe a csoportba, valamint az idősebb, 25-29 éves korosztály tagjai is. A regressziós együtthatók értékeit elemezve azt láthatjuk, hogy egy felsőfokú végzettségű apa gyerekének 1/0,405 azaz 2,47-szeres esélye van, hogy ide kerüljön egy középfokú végzettségűhöz képest. Egy alapfokú végzettségünek pedig $1 / 0,177=8,55$-ször kisebb az esélye a felsőfokúhoz képest, hogy a magaskultúra-orientált csoportba kerüljön. Kárpátalján a „magaskultúra orientáltak” csoportjában a differenciáló tényező inkább a nem, így a nők esélye a magaskultúra-orientáltak csoportjában 2,3-szoros a férfiakéhoz képest. A 2016-os ${ }^{39}$ felmérés eredményei részben mást mutatnak, nevezetesen azt, hogy a magaskultúra-orientáltak csoportjában a férfiak, míg a mindenevők csoportjában inkább a nők vannak felülreprezentálva. Bár a regressziós modell nem mutat szignifikáns összefüggéseket a „magaskultúra-orientáltak” csoportjában, a kereszttábla (lásd a mellékletben az 5. táblázatot) eredményei alapján azt mondhatjuk, hogy inkább a felsőfokú végzettséggel rendelkező, vezető beosztású szülők gyerekei vannak ebben a csoportban. A vajdasági fiatalok körében szintén kirajzolódik egy markáns ,,magaskultúra-orientált" fogyasztói csoport, és Erdélyhez hasonlóan az apa iskolai végzettsége differenciál. Egy alapfokú végzettségü apa gyerekének 1/0,279, azaz 3,58-ször kisebb esélye van, hogy bekerüljön, és egy középfokúnak pedig 1/0,470=2,12-szer kisebb az esélye a felsőfokúhoz képest. Tehát minél magasabb végzettségü apától származik valaki, annál inkább magaskultúra-orientált. Az apa foglalkozása, a nem és az életkor nem mutatnak szignifikáns összefüggést. Régiók szerint Felvidéken van a legtöbb „magaskultúra-orientált” fiatal (28\%), 10 százalékkal több, mint Kárpátalján (18\%), ez az arány itt a legkevesebb. Míg a Vajdaságban inkább az iskolai végzettség, addig Felvidéken inkább a foglalkozás differenciál. Foglalkozás szerint a vállalkozók gyerekeinek kétszer, a vezetők gyerekeinek pedig hétszer nagyobb esélyük van ebbe a csoportba kerülni, mint a nyugdíjasok és egyéb inaktív apák gyerekeinek. Nemek tekintetében pedig az előző régiókhoz hasonlóan (Erdély, Kárpátalja) a nők háromszor nagyobb eséllyel tartoznak a magaskultúra-orientáltak csoportjába, mint a férfiak (3. táblázat).

„, Screenagereknek” neveztük azt a csoportot, akik inkább a médiaorientált tevékenységeket preferálják, nem vagy kevés érdeklődést mutatnak a kulturális szabadidős tevékenységek iránt, ugyanakkor a többi szabadidős tevékenységben is ritkábban vesznek részt. Erdélyben kétszer nagyobb eséllyel tartoznak a férfiak ebbe a csoportba, illetve közel kétszer nagyobb az esélye, hogy az idősebb

39 Szabó - Hires, 2018. 340. 
3. táblázat. Az egyes kulturális csoportokba való tartozást befolyásoló tényezök. Logisztikus regressziós modellek együtthatóinak exponenciális értékei, Exp (b) „Screenagerek"

\begin{tabular}{lllll}
\hline Magyarázó változók & Erdély & Kárpátalja & Vajdaság & Felvidék \\
\hline Apa iskolai végzettsége & & & & \\
\hline Alapfokú & 0,677 & $0,444^{*}$ & 2,162 & 1,227 \\
\hline Középfokú & $2,160^{* *}$ & 0,841 & 1,728 & 1,526 \\
\hline Apa jelenlegi foglalkozása & & & & \\
\hline $\begin{array}{l}\text { Beosztott, alkalmazott (nem köz- } \\
\text { szférában vagy közszférában) }\end{array}$ & 1,035 & $2,858^{* *}$ & 1,177 & 1,620 \\
\hline Vezetö beosztású & 1,146 & 1,181 & 1,346 & 1,542 \\
\hline Alkalmi munkából él meg & 1,065 & $2,576^{* *}$ & 1,111 & 2,399 \\
\hline Egyéni vállalkozó, társtulajdonos & 0,682 & 1,440 & 0,582 & 1,175 \\
\hline Korcsoport & & & & \\
\hline $15-19$ évesek & $1,490^{*}$ & 1,089 & $1,946^{*}$ & 0,922 \\
\hline 20-24 évesek & 1,089 & 1,399 & $2,818^{* *}$ & 0,979 \\
\hline Nem & \multicolumn{5}{l}{} \\
\hline Férfi & $2,119^{* *}$ & $1,966^{* *}$ & 1,269 & $2,027^{* *}$ \\
\hline Konstans & 0,155 & 0,213 & 0,106 & 0,106 \\
\hline Nagelkerke R Square & 0,095 & 0,100 & 0,085 & 0,053 \\
\hline
\end{tabular}

Referenciakategóriák: Felsőfokú végzettség, Egyéb (nyugdíjas, háztartásbeli- inaktív), 25-29 évesek, férfi $* p<0,05 ; * * p<0,01$.

korosztályhoz viszonyítva inkább a 15-19 évesek legyenek screenagerek. Az iskolázottság tekintetében, a felsőfokú végzettekhez viszonyítva a középfokú tanulmányokkal rendelkező apák gyerekeinek közel kétszer akkora esélye van arra, hogy a screenagerek csoportjában tartozzanak, mint egy másik csoportba. A kárpátaljai adatokat elemezve szintén nagyobb eséllyel tartoznak a férfiak ide. Továbbá az apa foglalkozása is hatással van a csoportba való kerülés esélyeire, közel háromszor nagyobb eséllyel kerülnek azok a fiatalok ebbe a csoportba, akiknek az apja alkalmi munkát végez, vagy beosztott/alkalmazott, az inaktívakhoz képest. Egy alapfokú végzettségü apa gyerekének 1/0,444=2,3-szor kisebb esélye van a felsőfokúhoz képest, hogy a screenagerek csoportjába kerüljön. Foglalkozása szerint pedig az inaktívakhoz képest kétszer nagyobb eséllyel tartoznak azok ide, akiknek apjuk alkalmazotti státussal rendelkezik, illetve azok, akik alkalmi munkából élnek meg. Vajdaságban a screenagerek csoportjában az életkor mutat szignifikáns összefüggést, közel kétszer nagyobb eséllyel tartoznak 15-19 évesek és háromszor nagyobb eséllyel 20-24 évesek. Felvidéken mindössze a nem tekintetében találtunk szignifikáns összefüggést, szintén nagyobb, kétszeres eséllyel tartoznak a férfiak, mint nők ebbe a fogyasztói csoportba. 
4. táblázat. Az egyes kulturális csoportokba való tartozást befolyásoló tényezök. Logisztikus regressziós modellek együtthatóinak exponenciális értékei, Exp (b) „Passzivak”

\begin{tabular}{|c|c|c|c|c|}
\hline Magyarázó változók & Erdély & Kárpátalja & Vajdaság & Felvidék \\
\hline \multicolumn{5}{|l|}{ Apa iskolai végzettsége } \\
\hline Alapfokú & $19,099^{* *}$ & $4,701^{* *}$ & 1,730 & 0,712 \\
\hline Középfokú & $2,728^{* *}$ & 0,964 & 1,190 & 0,565 \\
\hline \multicolumn{5}{|l|}{ Apa jelenlegi foglalkozása } \\
\hline $\begin{array}{l}\text { Beosztott, alkalmazott (nem köz- } \\
\text { szférában vagy közszférában) }\end{array}$ & $0,609^{*}$ & 0,471 & 0,890 & $0,280^{* *}$ \\
\hline Vezető beosztású & 0,541 & 0,592 & 0,500 & $0,062^{* *}$ \\
\hline Alkalmi munkából él meg & 1,777 & 1,476 & 1,022 & 1,320 \\
\hline Egyéni vállalkozó, árstulajdonos & $0,217^{* *}$ & 0,845 & 1,055 & $0,234^{* *}$ \\
\hline \multicolumn{5}{|l|}{ Korcsoport } \\
\hline 15-19 évesek & $0,381^{* *}$ & $0,278^{* *}$ & $0,323^{* *}$ & $0,553^{*}$ \\
\hline 20-24 évesek & $0,483^{* *}$ & 0,604 & $0,419^{* *}$ & $0,552^{*}$ \\
\hline \multicolumn{5}{|l|}{ Nem } \\
\hline Férfi & 1,210 & 1,527 & 1,103 & 1,464 \\
\hline Konstans & 0,177 & 0,246 & 0,558 & 2,113 \\
\hline Nagelkerke R Square & 0,311 & 0,246 & 0,085 & 0,155 \\
\hline
\end{tabular}

Referenciakategóriák: Felsőfokú végzettség, Egyéb (nyugdíjas, háztartásbeli- inaktív), 25-29 évesek, nỏ $* p<0,05 ; * * p<0,01$.

Végül a „passzívak” csoportját elemezve a regressziós modellünk Erdélyben azt mutatja, hogy az alacsony iskolázottságú szülők gyerekeinek jóval nagyobb az esélye, hogy a passzívak csoportjába tartozzanak, mint a másik háromba. Tehát ezt a klasztert az alacsonyabb iskolai végzettség és az idősebb életkor jellemzi. Ugyanakkor szignifikáns összefüggés van az apa foglalkozása és a csoporthovatartozás között: egy egyéni vállalkozó gyerekének 1/0,217=4,6-szor kisebb a valószínüsége, hogy a passzívak csoportjába kerüljön az inaktívakhoz képest, az alkalmi munkából élők gyerekeinek pedig kétszer nagyobb.

Az apa iskolázottsága Kárpátalján is szignifikáns összefüggést mutat, egy alacsony iskolai végzettségü apa gyerekének közel ötször nagyobb az esélye, hogy ebbe a csoportba kerüljön, mint a másik háromba. Életkor szerint az erdélyi mintához hasonlóan az idősebbek nagyobb eséllyel tartoznak a passzívak csoportjába. Vajdaságban és Felvidéken az életkor szintén szignifikáns összefüggést mutat. A 15-19 éveseknek kisebb az esélyük ide tartozni, tehát ebben a csoportban inkább a 25-29 évesek vannak jelen. Felvidéken az apa foglalkozása és a „passzívak” csoportjába való tartozás szintén szignifikáns összefüggést mutat. A vezető apa gyerekének 1/0,062=16,13-szor, illetve az egyéni vállalkozó és alkalmazotti státussal rendelkező apa gyerekének négyszer kisebb esélye van a „passzívak” csoportjába kerülni, mint az inaktívaknak. 
Vajdaságban - de véleményünk szerint mindegyik vizsgált régióban - a rendszerváltás megkésettsége miatt a fiatalok még specifikusabb kockázatoknak vannak kitéve, és a szociális átalakulás legfőbb jellemzője, hogy kialakul egy kis elitcsoport, a társadalom nagyobbik része pedig lecsúszik a társadalmi ranglétrán ${ }^{40}$, ami a kulturális fogyasztói csoportok kialakulásában is visszatükröződik, így van egy jól elkülönülő „magaskultúrafogyasztói” illetve egy „mindenevő” csoport, de ugyanakkor egy nagyszámú ,passzív” réteg is.

\section{Következtetések}

Célunk az volt, hogy betekintést nyújtsunk a Kárpát-medencei, 15-29 éves magyar fiatalok szabadidős kulturális fogyasztási szokásaiba. A szabadidős színtereket elemezve négy fogyasztói szegmenst határoztunk meg: a mindenevők, a magaskultúra-orientáltak, a screenagerek és a passzívak csoportját.

A fogyasztói csoportokat vizsgálva azt láthattuk, hogy a két legmarkánsabb csoport a „screenagerek” és a „passzívak” csoportja. A legtöbb screenager fiatal Kárpátalján és Erdélyben van, a fiatalok 34, illetve 29 százaléka tartozik ide, Vajdaságban és Felvidéken pedig a „passzívak” csoportjába tartoznak legtöbben, a fiatalok 28 százaléka.

A magaskultúra fogyasztás leginkább a felvidéki és a vajdasági fiatalokra jellemző, a fiatalok 28, illetve 25 százaléka tartozik a „magaskultúra-orientáltak” csoportjába, míg Kárpátalján a megkérdezetteknek csak a 18 százaléka. Az erdélyi fiatalok helyzete abból a szempontból sajátos, hogy Erdélyben van a legtöbb „mindenevő” fiatal, akiknek szabadidős aktivitására szintén nagy arányban jellemző a magaskultúra fogyasztása.

Az elemzés a továbbiakban arról tanúskodik, hogy a kultúrafogyasztás szorosan összefügg a társadalmi rétegződéssel ${ }^{41}$, a kulturális aktivitás növekszik az egyén, illetve a szülő státusával. Bukodi szerint a volt kommunista országokban a kulturális fogyasztás alakulását legerősebben az iskolai végzettség befolyásolja, különösen az apa státusát emeli ki, ami a volt szocialista országokban még a rendszerváltást követően is erős hatással van kulturális rétegződésre. ${ }^{42}$

40 Szerbhorváth György: Ifjúságkutatások Szerbiában. In. Papp Z. Attila (szerk.) Változó kisebbség. Kárpát medencei magyar fiatalok. GeneZYs 2015 kutatás eredményei. Budapest, 2017 pp. 151-171.

41 Fábián Zoltán - Kolosi Tamás - Róbert Péter: Fogyasztás és életstílus. In. Kolosi Tamás Tóth István György -Vukovich György (szerk.): Társadalmi Riport. Budapest: Tárki, 2000. 225-259.

42 Bukodi, 2010. 
Elemzésünk jól mutatja, hogy a magas iskolai végzettséggel, illetve a szubjektív anyagi jóléttel ${ }^{43}$ együtt jár a színesebb, sokrétübb szabadidőfogyasztás. Az apa iskolázottsága jelentősen befolyásolja a csoporthovatartozást, azaz minél alacsonyabb végzettséggel rendelkezik az apa, annál nagyobb valószínűséggel kerül gyereke a „passzívak” csoportjába, és ugyanakkor a magasabb iskolai végzettségüek nagyobb valószínűséggel kerülnek a „magaskultúra-orientáltak” csoportjába. Felvidék az egyedüli régió, ahol nincs összefüggés az apa iskolai végzettsége és a csoporthovatartozás között. Ez az összefüggés Erdélyben és Felvidéken a legerősebb - a „mindenevők” és a „passzívak” csoportjában. Azt láthatjuk, hogy Erdélyben egy vezető beosztású apa vagy egy egyéni vállalkozó gyereke sokkal nagyobb valószínüséggel lesz kulturális mindenevő, illetve Felvidéken nagyobb valószínüséggel kerül a magaskultúra fogyasztóinak csoportjába.

Az apa iskolai végzettsége és foglalkozása mellett az életkor és a nem szintén szignifikáns összefüggést mutat. Minél fiatalabb valaki, annál inkább tartozik a „mindenevők” csoportjába, különösen igaz ez Erdélyben, Kárpátalján és Felvidéken, illetve kivétel nélkül mindegyik régióban a passzívak csoportjába inkább az idősebbek tartoznak. A Vajdaságban nincs szignifikáns kapcsolat a csoporthovatartozás és a nemek tekintetében, viszont a másik három régióban a „screenagerek” csoportjában nagyobb valószínűséggel vannak jelen a férfiak, míg a nők inkább kulturális mindenevők (Erdély, Kárpátalja) vagy magaskultúra fogyasztók (Kárpátalja, Felvidék).

Ha a régiókat egy szabadidős tengelyen képzeljük el, azt láthatjuk, hogy minden régióban a fiatalok egy rétege, közel 30 százalékuk a „passzívak” csoportjába tartozik. Ugyanakkor mindegyik régióhoz kapcsolható egy sajátos szabadidős aktivitás: az erdélyi fiatalok szabadidős mintázata a legszínesebb, ők a legaktívabbak a szabadidős palettán. Erdélyben vannak a legkevesebben a passzívak csoportjában és legtöbben a kulturális mindenevők csoportjában. ${ }^{44} \mathrm{~A}$ felvidéki és vajdasági fiatalok körében van a legtöbb „magaskultúra”- fogyasztó, de ugyanakkor a legtöbb passzív fiatal is. A kárpátaljai fiatalok szabadidejére a médiaorientált tevékenységek preferálása jellemző. Tehát a szabadidő és a kulturális fogyasztás tekintetében az erdélyi és kárpátaljai fiatalok különböznek leginkább, a vajdasági és a felvidéki fiatalok állnak a legközelebb egymáshoz.

Az a megközelítés, mely szerint a fogyasztói társadalom kialakulása lehetőséget adott a fiataloknak, hogy elszakadjanak a hagyományos osztályalapú identitásuktól, és a megnövekedett vásárlóerejük következtében lehetőségük adódott a saját maguk által formált új identitás alakítására ${ }^{45}$ csak részben igaz a kelet-európai, pontosabban az erdélyi, felvidéki, kárpátaljai és a vajdasági fiatalokra. Ugyanis

43 Lásd a mellékletekben az 5-8. táblázatokat.

44 Hasonló eredményeket mutatnak a 2016-os Ifjúsági felmérés eredményei is. L. Szabó - Hires, 2018.

45 Bennett, 2005. 
a családi háttér (az iskolai végzettség, a foglalkozás) még mindig nagyon erősen meghatározza fogyasztói magatartásukat a szabadidő eltöltésben. ${ }^{46}$ Fontos kiemelnünk, hogy a vizsgált régiókban, különösen Erdélyben és Kárpátalján a magasabb státusú/réteghelyzetü, magaskultúrát fogyasztó fiatalok mellett megjelent egy mindenevő fogyasztói csoport, akiket leginkább a középosztályisággal asszociálunk, a nagyvonalú, illetve diszkrecionális fogyasztási mintázattal.

Az elemzés során az is érzékelhető, hogy a szabadidő eltöltésben egyre fontosabbá válik az elektronikus média, egyre nagyobb teret kapnak a digitális kultúra eszközei, ${ }^{47}$ viszont figyelemre méltóbb eredménynek tartjuk a „magaskultúra” fogyasztói csoport mellett megjelenő „mindenevők” csoportját, ${ }^{48}$ ami azt jelenti, hogy a fiatalok egy rétegére a sokszínű szabadidőeltöltés jellemző, viszont legalább egy ugyanekkora szegmense a fiataloknak passzívan tölti el a szabadidejét. Ez azt jelenti, hogy a Kárpát-medence magyar fiataljai körében - a magyarországi fiatalokéhoz hasonlóan - a kulturális rétegződés inkább egy „mindenevő - passzív” tengely mentén rendeződik el, mintsem egy elit-tömegkultúra tengelyen. ${ }^{49}$

46 Sági, 2010.; Fekete - Prazsák, 2014.; Szabó, 2018.

47 Nagy 2013.; Székely, 2017.

48 Chan - Goldthorpe 2005.; Sági, 2010.; Fekete - Prazsák, 2014.; Szabó, 2018.

49 Sági, 2010. 


\section{MELLÉKLETEK}

5. táblázat. Társadalmi demográfiai csoportok kulturális klasztereken belüli aránya. Kárpátalja (\%)

Társadalmi-demográfiai csoport

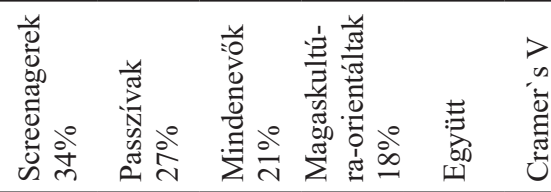

Apa iskolai végzettsége ${ }^{* *}$

Alapfokú

Középfokú

Felsőfokú

Apa foglalkozása**

Beosztott (közszférában, nem

közszférában)

Vezető beosztású

Alkalmi munkából él meg

Egyéni vállalkozó, társtulajdonos

Egyéb (inaktív, nyugdíjas stb.)

Korcsoport $^{* *}$

15-19 évesek

20-24 évesek

25-29 évesek

$\mathrm{Nem}^{* *}$

Nö

Férfi

Szubjektív anyagi jólét ${ }^{* *}$

Gondok nélkül él

Beosztással jól kijön

Éppen, hogy meg tud élni

Hónapról-hónapra anyagi gondok vannak

Nélkülözik

Településtípus*

Város

Falu

Családi állapot $^{* *}$

Egyedülálló

Van párkapcsolata, de nem élnek együtt

Házas

Nem házas, de együtt él valakivel

Elvált, külön él

$\begin{array}{rrrrr}14,4 & 44,8 & 8,4 & 11,7 & 20,6 \\ 51,0 & 36,2 & 64,2 & 49,4 & 49,7 \\ 34,6 & 19,0 & 27,4 & 39,0 & 29,7\end{array}$

, 205

$\begin{array}{lllll}40,1 & 16,9 & 33,3 & 35,1 & 31,6\end{array}$

$\begin{array}{rrrrr}2,0 & 0,8 & 2,2 & 5,4 & 2,3\end{array}$

$\begin{array}{rrrrr}30,9 & 42,4 & 20,4 & 9,5 & 28,1\end{array}$

$\begin{array}{rrrrr}11,8 & 10,2 & 23,7 & 14,9 & 14,4\end{array}$

$\begin{array}{llllll}15,1 & 29,7 & 20,4 & 35,1 & 23,6\end{array}$

, 265 
6. táblázat. Társadalmi demográfiai csoportok kulturális klasztereken belüli aránya. Vajdaság (\%)

\begin{tabular}{|c|c|c|c|c|c|c|}
\hline $\begin{array}{l}\text { Társadalmi-demográ- } \\
\text { fiai csoport }\end{array}$ & 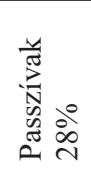 & 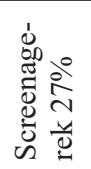 & 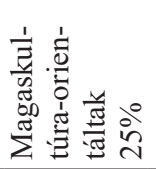 & 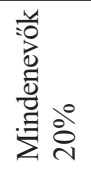 & $\begin{array}{l}\text { 黄 } \\
\text { 总 } \\
\text { 恶 }\end{array}$ & 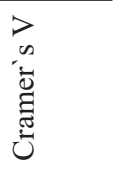 \\
\hline Apa iskolai végzettsége* & & & & & &, 122 \\
\hline Alapfokú & 23,4 & 20,2 & 11,8 & 14,1 & 17,8 & \\
\hline Középfokú & 65,3 & 71,4 & 68,2 & 75,3 & 69,6 & \\
\hline Felsőfokú & 11,3 & 8,4 & 20,0 & 10,6 & 12,6 & \\
\hline Korcsoport ${ }^{* *}$ & & & & & &, 185 \\
\hline 15-19 évesek & 18,9 & 33,1 & 34,2 & 34,8 & 29,7 & \\
\hline 20-24 évesek & 26,8 & 43,8 & 34,2 & 29,2 & 33,7 & \\
\hline 25-29 évesek & 54,3 & 23,1 & 31,6 & 36,0 & 36,6 & \\
\hline
\end{tabular}

Khi négyzetek: $13.125 ; 30.729$;

* $p<0,05 ; * * p<0,01$. Apa foglalkozása, nem, szubjektív jólét, településtípus, családi állapot - nem szignifikáns 
7. táblázat. Társadalmi demográfiai csoportok kulturális klasztereken belüli aránya. Felvidék (\%)

\begin{tabular}{|c|c|c|c|c|c|c|}
\hline $\begin{array}{l}\text { Társadalmi-demográfiai } \\
\text { csoport }\end{array}$ & 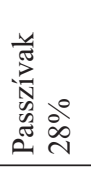 & 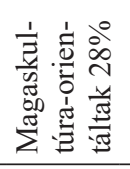 & 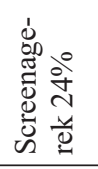 & 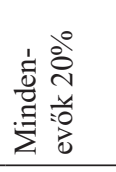 & $\begin{array}{l}\text { 帚 } \\
\text { 离 } \\
\end{array}$ & 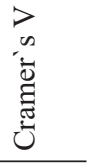 \\
\hline Apa foglalkozása $^{* *}$ & & & & & &, 210 \\
\hline $\begin{array}{l}\text { Beosztott (közszférában, nem } \\
\text { közszférában) }\end{array}$ & 45,2 & 50,3 & 60,2 & 60,0 & 53,1 & \\
\hline Vezető beosztású & 1,9 & 12,6 & 6,8 & 4,8 & 6,7 & \\
\hline Alkalmi munkából él meg & 9,0 & 0 & 5,3 & 1,9 & 4,2 & \\
\hline Egyéni vállalkozó, társtulajdonos & 15,5 & 27,0 & 17,3 & 27,6 & 21,6 & \\
\hline Egyéb (inaktív, nyugdíjas stb.) & 28,4 & 10,1 & 10,5 & 5,7 & 14,5 & \\
\hline Korcsoport $^{* *}$ & & & & & &, 160 \\
\hline 15-19 évesek & 16,9 & 30,6 & 23,1 & 30,3 & 24,9 & \\
\hline 20-24 évesek & 30,2 & 33,5 & 36,1 & 47,1 & 35,8 & \\
\hline $25-29$ évesek & 52,9 & 35,8 & 40,8 & 22,7 & 39,3 & \\
\hline $\mathrm{Nem}^{* *}$ & & & & & & 250 \\
\hline Nö & 40,5 & 67,6 & 36,5 & 50,0 & 49,0 & \\
\hline Férfi & 59,5 & 32,4 & 63,5 & 50,0 & 51,0 & \\
\hline Szubjektív anyagi jólét ${ }^{* *}$ & & & & & &, 161 \\
\hline Gondok nélkül él & 15,5 & 25,6 & 17,4 & 33,6 & 22,4 & \\
\hline Beosztással jól kijön & 54,8 & 65,7 & 55,6 & 56,3 & 58,4 & \\
\hline Éppen, hogy meg tud élni & 25,6 & 7,0 & 23,6 & 10,1 & 16,7 & \\
\hline $\begin{array}{l}\text { Hónapról-hónapra anyagi gondok } \\
\text { vannak }\end{array}$ & 3,0 & 1,7 & 2,8 & 0,0 & 2,0 & \\
\hline Nélkülözik & 1,2 & 0,0 & 0,7 & 0,0 & 0,5 & \\
\hline Családi állapot $^{* *}$ & & & & & &, 134 \\
\hline Egyedülálló & 34,1 & 50,9 & 45,5 & 47,0 & 44,1 & \\
\hline $\begin{array}{l}\text { Van párkapcsolata, de nem élnek } \\
\text { együ̈tt }\end{array}$ & 28,7 & 30,2 & 33,1 & 39,3 & 32,3 & \\
\hline Házas & 15 & 7,7 & 6,9 & 4,3 & 8,9 & \\
\hline Nem házas, de együtt él valakivel & 20,4 & 10,7 & 14,5 & 9,4 & 14 & \\
\hline Elvált, külön él & 1,8 & 0,6 & 0 & 0 & 0,7 & \\
\hline
\end{tabular}

Khi negyzetek:73.012; 31.340; 38.394; 46.663; 32.102

$* p<0,05 ; * * p<0,01$. Apa Iskolai végzettsége, településtípus - nem szignifikáns 
8. táblázat. Társadalmi demográfiai csoportok kulturális klasztereken belüli aránya. Erdély (\%)

Társadalmi-demográfiai csoport
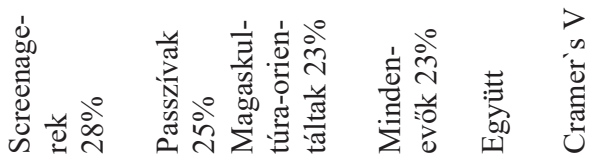

Apa iskolai végzettsége ${ }^{* *}$

\begin{tabular}{lrrrrrr}
\hline Alapfokú & 6,8 & 38,6 & 5,2 & 4,3 & 13,4 & \\
\hline Középfokú & 78,8 & 54,8 & 58,1 & 66,5 & 65,5 & \\
\hline Felsőfokú & 14,4 & 6,6 & 36,6 & 29,3 & 21,1 & \\
\hline Apa foglalkozása* & & & & & &, 221 \\
\hline $\begin{array}{l}\text { Beosztott (közszférában, nem } \\
\text { közszférában) }\end{array}$ & 55,7 & 35,0 & 50,0 & 61,9 & 50,8 & \\
\hline Vezetö beosztású & 7,8 & 2,5 & 8,1 & 9,5 & 7,0 & \\
\hline Alkalmi munkából él meg & 10,7 & 22,8 & 5,6 & 3,7 & 10,7 & \\
\hline Egyéni vállalkozó, társtulajdonos & 7,8 & 2,0 & 13,6 & 14,8 & 9,4 & \\
\hline Egyéb (inaktív, nyugdíjas stb.) & 18,0 & 37,6 & 22,7 & 10,1 & 22,0 & \\
\hline Korcsoport & & & & & &, 198 \\
\hline 15-19 évesek & 35,2 & 17,2 & 18,1 & 42,0 & 28,2 & \\
\hline $20-24$ évesek & 35,6 & 31,0 & 42,8 & 35,7 & 36,2 & \\
\hline $25-29$ évesek & 29,2 & 51,7 & 39,1 & 22,2 & 35,6 & \\
\hline Nem ${ }^{* *}$ & & & & & &, 188 \\
\hline Nö & 37,5 & 44,4 & 53,5 & 62,3 & 48,6 & \\
\hline Férfi & 62,5 & 55,6 & 46,5 & 37,7 & 51,4 &
\end{tabular}

Szubjektív anyagi jólét ${ }^{* *}$ , 419

Gondok nélkül él

Beosztással jól kijön

$\begin{array}{rrrrr}22,2 & 13,8 & -18,7 & 30,0 & 21,0 \\ 66,7 & 44,4 & 74,8 & 61,8 & 61,8\end{array}$

Éppen, hogy meg tud élni

$\begin{array}{rrrrr}8,0 & 16,8 & 3,7 & 5,3 & 8,6\end{array}$

Hónapról-hónapra anyagi gondok vannak

$3,1 \quad 22,4 \quad 2,8 \quad 2,9 \quad 7,9$

\begin{tabular}{lcccccc}
\hline Nélkülözik & 0,0 & 2,6 & 0,0 & 0,0 & 0,7 & \\
\hline Településtípus** & & & & & &, 176 \\
\hline Város & 52,3 & 34,5 & 56,3 & 55,3 & 49,4 & \\
\hline Falu & 47,7 & 65,5 & 43,7 & 44,7 & 50,6 & \\
\hline Családi állapot $^{* *}$ & & & & & &, 214 \\
\hline Egyedülálló & 58,7 & 38,8 & 41,1 & 48,1 & 47,2 & \\
\hline Van párkapcsolata, de nem élnek együtt & 25,4 & 13,4 & 34,1 & 38,0 & 27,2 & \\
\hline Házas & 9,1 & 30,6 & 15 & 5,8 & 15,1 & \\
\hline Nem házas, de együtt él valakivel & 5,3 & 17,2 & 8,9 & 7,7 & 9,7 & \\
\hline Elvált, külön él & 1,5 & 0 & 0,5 & 0 & 0,5 & \\
\hline Özvegy & 0 & 0 & 0,5 & 0,5 & 0,2 & \\
\hline
\end{tabular}

Khi négyzetek: $186.863 ; 121.249 ; 71.698 ; 32.315 ; 160.221 ; 28.480 ; 126.179 ; \quad * p<0,05 ; * * p<0,01$

REGIO 28. évf. (2020) 4. szám 44-71. 


\section{FELHASZNÁLT IRODALOM}

Barna Gergő: Szabadidő, kultúra, média, internet - román és magyar fiatalok fogyasztási szokásai. In: Kiss Tamás - Barna Gergő (szerk.): Erdélyi magyar fiatalok. Összehasonlitó elemzés. Kolozsvár: Nemzeti Kisebbségkutató Intézet, 2011.91-151.

Baudrillard, Jean: Societatea de consum. Mituri şi structuri. Bucureşti: Editura Comunicare, 2008.

Baudrillard, Jean: A tárgyak rendszere. Budapest: Gondolat kiadó, 1987.

Beck, Ulrich: Mi a globalizáció? Szeged: Belvedere, 2005.

Bennett, Andy: Szubkulturák vagy neo törzsek? A fiatalok, a stílus és a zenei ízlés közötti kapcsolat újragondolása. Replika, 2005/53. 127-145.

Bourdieu, Pierre: Különbségek és megkülönböztetések. In: uő: A társadalmi egyenlötlenségek újratermelödése. Budapest: Gondolat Kiadó, 1978, 136-151. Bourdieu, Pierre: Distinction: A Social Critique of the Judgement of Taste. Harvard Univerity Press, 1984.

Bukodi Erzsébet: Social stratification and cultural participation in Hungary: a post-communist pattern of consumption? In: Chan, Tak Wing - Goldthorpe, John (ed.): Social Status and Cultural Consuption. Cambridge University Press, 2010. 139-168.

Campbell, Colin: A modern fogyasztói étosz rejtélye. Replika, 1996, 21-22. 117-137.

Chan Tak Wing - Goldthorpe, H. John: The Social Stratification of Theatre, Dance and Cinema Attendance. Cultural Trends, 2005. Vol. 14(3). No.55, 193-212. Elérhető: http://users.ox.ac.uk/ sfos0006/papers/ct2005.pdf

Chan, Tak Wing - Goldthorpe, H. John: Social stratification of Cultural Consumption. The visual arts in England. Poetics, 2007. 35 (2-3). 168-190. Elérhetö: http://dx.doi.org/https://doi.org/10.1017/cbo9780511712036.008.

Chan, Tak Wing - Goldthorpe, H. John: Social Status and Cultural Consumption. In: Chan, T. W. - Goldthorpe, J. (szerk.) Social Status and Cultural Consumption. Cambridge University Press, 2010. 1-28.

Chan, Tak Wing: Understanding Cultural Omnivores: Social and Political Attitudes, 2013. Elérhető: http://users.ox.ac.uk/ sfos0006/papers/att3.pdf

Chisholm, Lynne: Élesebb lencse vagy új kamera? In: Gábor Kálmán (szerk.): Civilizációs korszakváltás és ifjúság. Szeged: Szociológiai Műhely, 1993. 49-70. Csernicskó István - Soós Kálmán. Kárpátalja: In Szabó Andrea - Bauer Béla Laki László - Nemeskéri István (szerk.). Mozaik2001 Gyorsjelentés, Nemzeti Ifjúságkutató Intézet. 91-137.

Ercsei Kálmán: Félsziget Fesztivál ifjúsága: Fesztiválok ifjúsága? Az iskolázottság és továbbtanulás összehasonlító vizsgálata az ifjúsági korszakváltás 
kontextusában. In: Ercsei Kálmán - Veres Valér (szerk.): WEB. Fesztiválok Ifjúsága. Kolozsvár: Cova-print, 2006. 47-63.

Ercsei Kálmán - Kiss Zita - Szabó Júlia: Fiatalok szabadidős fogyasztása, önállósodása és jövőképe a marosvásárhelyi Félsziget-vizsgálatok alapján. In: Kiss Tamás. - Barna Gergő (szerk.): Erdélyi magyar fiatalok. Összehasonlitó elemzés. Kolozsvár: ISPMN - Kriterion Könyvkiadó, 2011. 233-260.

Fekete Mariann - Prazsák Gergö: Kulturális kasztrendszer: Autonómia és közösségiség szerepe a fiatalok kulturális aktivitásában. In: Nagy Ádám - Székely Levente: Másodkézböl. Magyar Ifjúság 2012. Budapest: ISZT Alapítvány-Kutatópont, 2014. 195-218.

Fekete Mariann: eIDÖ, AVAGY A SZABADIDÖ BEHÁLÓZÁSA. Generációs kultúrafogyasztás a digitális korban. Szeged: Belvedere Meridionale, 2018.

Fábián Zoltán - Kolosi Tamás - Róbert Péter: Fogyasztás és életstílus. In. Kolosi Tamás - Tóth István György -Vukovich György (szerk.): Társadalmi Riport. Budapest: Tárki, 2000. 225-259.

Gábor Kálmán: Globalizáció és korszakváltás. In: Gábor Kálmán - Jancsák Csaba (szerk.): Ifjúsági korszakváltás. Ifjúság az új évezredben. Szeged: Belvedere, 2004. 28-72.

Gábor Kálmán: Magyar fiatalok a világkockázati társadalomban. Korunk, 2009/2. 76-85.

Gábor Kálmán - Veres Valér: Transformarea socială şi tineretul în Europa de Est. Situaţia tinerilor maghiari din România. In: Kiss Tamás - Barna Gergő - Kozák Gyula (coord.): Tinerii maghiari din România. Dimensiuni comparative. Cluj Napoca: Ed. ISPMN - Ed. Kriterion, 2011. 39-56.

Hanquinet, Laurie: Inequalities: when culture becomes a capital. In: O'Brien, D. Miller, T. - Durrer, V. (szerk.): The Routledge Handbook of Global Cultural Policy. London: Routledge, 2017.

Hetesi Erzsébet: A fogyasztás szociológiája. In. Czagány László - Garai László (szerk.) A szociális identitás, az információ és a piac. Szeged, SZTE Gazdaságtudományi Kar Közleménye. JATEPress, 2004. 267-281

Kristóf Luca - Kmetty Zoltán: Szereti Ön Vivaldit? Zenei ízlés és társadalmi státusz. Szociológiai Szemle, 2019/2. 49-67.

Muggleton, David: Inside Subculture. The Postmodern Meaning of Style. Oxford: Berg, 2000.

Nagy Ádám: Szabadidős tervek és tevékenységek. In: Székely Levente (szerk.): Magyar Ifjúság 2012 Tanulmánykötet. Kutatópont, 2013.

Peterson, Richard A. - Simkus, Albert: How musical tastes mark occupational status groups. In: Lamont, M. - Fournier, M. (ed.) Cultivating differences: Symbolic boundaries and the making of inequality. Chicago: University of Chicago Press, 1992. 152-186. 
Peterson, Richard A. - Kern, Roger: Changing Highbrow Taste: From Snob to Omnivore. American Sociological Review, 1996. 61 (5). 900-907. Elérhetö: http:// dx.doi.org/10.2307/2096460.

Savage, Mike - Devine, Fiona - Cunningham, Niall - Taylor, Mark - Li, Yaojun - Hjellbrekke, Johs - Le Roux Brigitte - Friedman, Sam - Miles, Andrew: A New Model of Social Class? Findings from the BBC's Great British Class Survey Experiment. Sociology, 2013. 47 (2). 219-250. Elérhetö: http://dx.doi. org/10.1177/0038038513481128.

Sági Matild: Kulturális szegmentáció: „mindenevők”, „válogatósak”, „egysíkúak” és „nélkülözők”? Az „omnivore-univore” modell alkalmazhatósága Magyarországon. In: Kolosi Tamás - Tóth István György (szerk.): Társadalmi riport. Budapest: Tárki, 2010. 288-311.

Szabó Andrea - Bauer Béla - Laki László - Nemeskéri István: Ifjúság 2000 Gyorsjelentés. Budapest: Nemzeti Ifjúságkutató Intézet, 2002.

Szabó Júlia: Kulturális szegmentáció az erdélyi magyar fiatalok körében. Socio.hu, 2018/3. 62-79.

Szabó Júlia - Hires-László Kornélia: Régi és új kultúra In: Székely Levente (szerk.): Magyar Fiatalok a Kárpát-medencében. Magyar Ifjúság Kutatás 2016, Budapest, 2018. 317-353.

Szerbhorváth György: Ifjúságkutatások Szerbiában. In. Papp Z. Attila (szerk.) Változó kisebbség. Kárpát medencei magyar fiatalok. GeneZYs 2015 kutatás eredményei. Budapest, 2017 pp. 151-171.

Veblen, Thorstein: The Theory of the Leisure Class. In: Social Stratifocation. Class, Race, and Gender in Sociological Perspective. ed. David B. Grusky (in collaboration with Manwai C. Ku and Szonja Szelényi). Stanford University: Westview Press, 2008. 862-870.

Veblen, Thorstein: A dologtalan osztály elmélete. Budapest: Közgazdasági és Jogi, 1975.

Veres Valér: Középosztályosodási tendenciák vizsgálata a marosvásárhelyi Fél-sziget Fesztivál résztvevői körében. In: Ercsei Kálmán - Veres Valér (szerk.) WEB Fesztiválok Ifjúsága. Kolozsvár: Cova-print,1-2, 2006. 35-47.

Veres Valér: A fiatalok munkaerő-piaci helyzete, a társadalmi közérzet és a problémaérzékelés rétegspecifikus életérései. In: Kiss Tamás - Barna Gergő (szerk.) Erdélyi magyar fiatalok. Összehasonlitó elemzés. Nemzeti Kisebbségkutató Intézet. Kolozsvár, 2011. 55-85.

Wallace, Claire: Ifjúság, munka és oktatás a posztkommunista Európában: út az individualizáció felé? Korunk, 1998/6. 5-12.

Zinnecker, Jürgen: A fiatalok a társadalmi osztályok terében. In: Gábor Kálmán: (szerk.): Civilizációs korszakváltás és ifjúság. Szeged: Szociológiai mühely, 1993. 5-28. 